\title{
KERK EN TEOLOGIE
}

\section{(Opsomming van referate gelewer by die G.E.S.)}

\section{Eerste referaat: Wat is teologie? deur Willie D. Jonker:}

IN ons huidige tydsgewrig, wat gekarakteriseer word deur 'n soeke na identiteit in al die wetenskappe, kom die brandende vraag na vore: wat is teologie? Vier modelle het in die verlede 'n belangrike rol gespeel:

1. Volgens die eerste model is teologie wysheid. Hierdie gedagtegang, waarvan Augustinus die klassieke eksponent was, was beheersend tot in die Middeleeue. Hiervolgens is teologie intellectus fidei. Die „kennis" van die teologie is 'n voorlopige fase van die wysheid wat vir ons 'n insig gee in die Wese van Godself. Met behulp van mistisisme en spekulasie word 'n teologiese kennis (gnosis) verkry wat meer is as die normale geloof. Die refleksie oor die Bybel en die openbaring van God is slegs voorbereidend vir die ware teologie.

2. Volgens die tweede model is teologie rasionele kennis van God. Anselmus, vader van die skolastisisme, aanvaar ook dat teologie intellectus fidei is, wat volgens die stelreël ontwikkel: fides quaerens intellectum; maar hy het geglo dat die geloof daarna moet strewe om die rasionele gronde van die geloofsinhoud vas te stel. Volgens Thomas van Aquinas, wat hierop voortborduur het, kan ons kennis van God verkry deur rasionele denkwyse oor God, met behulp van sekere waarhede uit die Bybel wat deur die Kerk geformuleer is. Hiervolgens kry ons 'n geobjektiveerde, ahistoriese sisteem van kennis van God waarin die kognitiewe element van die geloof totaal geïsoleer word van die belewenis van Gods genade en die gemeenskap met God, wat so prominent figureer in die Bybelse opvatting van die kennis van God.

3. Die derde model is dié van die Reformatore wat teologie gedefinieer het as die aandagtig luister na die Heilige Skrif, met die oog op interpretasie tot geloofversterking. Die Reformatore het die eerste en tweede modelle verwerp. Hulle het die Skolastisme met sy filosofiese en spekulatiewe tendense afgekeur en die kennis van God in 'n uitsluitlike Bybelse sin besien. Die teologie moet nie die mens se metafisiese vrae beantwoord nie, maar moet 'n sistematiese eksposisie van Bybelse waarhede gee - soos deur die geloof gegryp - om diegene te lei wat moet preek en wat die Bybel wil verstaan. Teologie is kennis van God in Christus, theologia crucis (Luther), binne die bane van die Skrif (Calvyn).

4. Die vierde model is dié van die neo-Protestante, naamlik: teologie is die studie van die mens se geloof of godsdienstige ervaring en aktiwiteit. Die fokus is nie op God en sy openbaring nie maar op die mens en sy geloof. Vanweë die nuwe benadering tot die wetenskap in die eeu van die Verligting, moes die teologie die vraag 
beantwoord of God as 'n objek van wetenskaplike kennis beskou kan word. Ook is daar 'n vraagteken geplaas agter die onfeilbare openbaring van God. Onder sterk druk van die empirisme, idealisme en positivisme het die neo-Protestantisme die openbaring van God as objek van die teologie vervang met die geloof of religieuse ervaring van die mens. Hierdie uitgangspunt kan aanleiding tot baie moontlikhede gee: teologie kan as neutrale wetenskap beskou word; dit kan 'n vorm van antropologie word (Bultmann); dit kan 'n marxisties-georiënteerde teorie van praktiese toepassing word (teologie van die revolusie); of dit kan as ' $n$ empiriese wetenskap beskou word wat moet omsien na die religieuse vrae van die gemeenskap (Kuitert).

Jonker kies die derde model, die Reformatoriese, as sy uitgangspunt. Dit beteken dat die openbaring van God in die Heilige Skrif die objek van die teologie is. Maar dan moet die Heilige Skrif absolute gesag dra as Woord van God. Ware teologie is Bybelse teologie. Omdat teologie na die Woord van God luister, kan dit 'n direkte invloed uitoefen op die geloof van die Kerk en sy aktiwiteite.

Natuurlik is teologie nie 'n absolute noodsaaklikheid nie. Geloof ontspring nie uit die teologie nie maar deur die Woord en die Heilige Gees. Maar die geloof moet tog versterk word en daarom is ondersoek van die Skrif nodig. Wat meer is: die Kerk moet die Woord verkondig en om dit te kan doen is refleksie oor die Skrif nodig. Teologie is dus 'n praktiese noodsaaklikheid - maar dan moet die Heilige Skrif sy eie interpres wees en nie volgens hermeneutiese beginsels buite die Bybel om beoordeel word nie.

Omdat die teologie ons die verstaan van die Woord vergemaklik, kan elke lewensfeer daaruit voordeel trek. Dit beteken egter nie dat die teologie alleenseggenskap het om die lig van die Skrif te versprei nie - nee, naas teologie is daar ook 'n Christelike wetenskap. Dit is nie die taak van die teoloog om alle vrae te beantwoord nie, omdat ander wetenskaplikes ook 'n taak het. Die teologie het geen monopolie op die korrekte interpretasie van die Skrif nie - alle wetenskappe het toegang tot die Bybel en moet dan ook hulle wetenskap in die lig van Gods Woord bestudeer. Natuurlik moet gedurige dialoog tussen teologie en ander wetenskappe plaasvind, sodat die teologie nie in 'n vakuum opereer nie. Maar dan moet die teologie nie sy konsentrasie op die Skrif verloor nie.

Is teologie 'n wetenskap? Op baie universiteite word dit nie so beskou nie. Die verlede het bewys dat as die openbaringsgedagte prysgegee word, word die teologie 'n neutrale wetenskap van die religie. Dit is geen wonder dat Karl Barth dan ook gesê het dal akademiese erkenning van die wetenskaplike aard van die teologif nie van primêre belang is nie. Ná Barth kry ons 'n sterk verdedigin! van die rasionele karakter van die teologie - beginnende by Bor hoeffer, Pannenberg en die neo-Marxisme met sy sterk aksent 0 'n wetenskap wat moet bevry.

Volgens Jonker is daar nog nie 'n duidelike verhouding tusse teologie en filosofie gegee nie. Wat teologie en die ander wete skappe betref: die teologie moet sy eie wetenskaplike kriteria or 
werp - dit kan hom nie onderwerp aan ander wetenskaplike kriteria wat hom hinder in sy ondersoek na die openbaring van God nie. Nooit mag die teologie sy eie identiteit prysgee nie.

\section{Kommentaar van B. Rietveld op Jonker se referaat:}

In sy kommentaar, wat waardering het vir die werk van Jonker, kom daar twee sinne voor waaragter ek vraagtekens plaas.

Eerste aanhaling: "Scripture itself is full of other religions ..." Dit is nie vir my duidelik wat Rietveld hiermee bedoel nie. Soos dit hier staan kan 'n mens die gedagte kry dat Rietveld geen prinsipiële verskil sien tussen die Christendom en ander wêreldgodsdienste nie - 'n gedagte wat ons natuurlik onvoorwaardelik afkeur; maar, soos ek sê, die sin is nie duidelik nie.

Tweede aanhaling: "Theology should indeed rule all departments as the science of sciences..." Hierdie stelling neig vir my na paternalisme. Aristoteles het die rasionele teologie bo die filosofiese metafisika gestel - 'n onderskeiding wat Thomas van Aquinas oorgeneem en met behulp van die natuurlike teologie gekanoniseer het. As die teologie paternalisties word, matig die teoloog hom aan om oor elke faset van die lewe uitsprake te doen, soos die Wêreldraad van Kerke hom tans aanmatig.

Tweede referaat: Theology, confession and the church deur Fred H. Klooster:

Klooster keer die volgorde om deur by die Kerk te begin en by die Teologie te eindig. Omdat konfessie en teologie met Koninkryk en Kerk te doen het, stel hy dit duidelik dat hy onder kerk slegs die institusionele kerk verstaan. Ná hierdie onderskeiding kom hy by die konfessie: Die Kerk wat by die Woord lewe, bely sy gemeenskaplike geloof in belydenisse. Sulke konfessies dui die interne geloofsband aan en lewer eksterne getuienis. Die konfessie verskil van die teologie. Teoloë en die teologie het grootliks gehelp om die konfessie op te stel, maar die formulerings bly konfessies en word nie teologie nie. Die konfessie reflekteer die teologie maar is nie teologie nie. Ná hierdie onderskeiding kom hy by die teologie: Teologie is ' $n$ besondere wetenskap. Dit vra teoretiese gedagtegang en sekondêre analise. Elke wetenskaplike gaan uit van 'n fundamentele religieuse stand - eksplisiet of implisiet. Totale objektiwiteit is onmoontlik. Hierdie uitgangspunt is die wetenskap se konfessie. Alle wetenskappe is konfessioneel. Wat die teologie van die ander wetenskappe onderskei is sy unieke veld van ondersoek. Die veld van ondersoek was aanvanklik kennis van God en later geopenbaarde kennis van God, maar met die koms van Kant en Schleiermacher het onduidelikheid gekom. Klooster maak die volgende onderskeiding:

1. Volgens die Gereformeerde teologie is die Heilige Skrif die veld van ondersoek.

2. Volgens Rooms-Katolieke teologie is die Heilige Skrif plus tradisie die veld van ondersoek. 


\section{In die Skriflig}

3. Volgens die liberale teologie is die religieuse ondervinding die veld van ondersoek.

Klooster se uitspraak is dat aldrie in die pistiese aspek betrek moet word. Daar is ook probleme wat die gesag in die teologie betref. Om te sê dat die Heilige Skrif alleen gesag het, is makliker gesê as gedoen. Kelsey wys bv. (David H. Kelsey: The Uses of Scripture in Recent Theology) hoe sewe verteenwoordigende teoloë hulle uiteenlopende teologie op die Skrif baseer. Hulle gebruik die Skrif om hulle teologiese konstruksies te bewys.

\section{Teologie en die konfessie}

Die teologie het as veld van ondersoek die konfessie van die kerk waarvan die teoloog lidmat is. Eerlikheid vereis dat hy die konfessie moet ondersoek wat hyself onderteken het. As die kerke die konfessie in sy bindende karakter ter syde stel, is dit nie meer 'n konfessionele kerk nie. Die konfessie is nie die dood van akademiese vryheid soos sommige beweer nie.

Gestel die teoloog vind dat die konfessie strydig is met die Heilige Skrif? Dan moet hy hom nie wend tot onetiese aktiwiteite nie maar hy moet die raad van kollegas inwin. Daarna moet hy die kerklike prosedure volg en dit is nodig dat die kerk hom simpatiek moet aanhoor. Ons leef in ' $n$ tyd van dekonfessionalisasie - as kerke nie die konfessie uitleef nie, hoe kan hulle dit dan van predikante verwag?

\section{Kerk en teologie}

Wat is die verhouding tussen kerk en teologie? Het die kerk werklik teologie nodig, nou dat teoloë soveel probleme vir die kerk meebring? Die antwoord is: die kerk moet die Woord spreek, sakramente bedien, die tug handhaaf - daarom is dit nie die spesifieke taak van die kerk om 'n teologiese wetenskap uit te bou nie. Oor die vraag of die teologie dan nie vir die bene esse van die kerk noodsaaklik is, as dit nie vir die esse is nie, is daar nie eenstemmigheid nie.

Wat die teorie ook al mag wees - die praktyk vra dat daar 'n noue band tussen die teoloë en die teologiese fakulteite moet wees met die oog op die opleiding van predikante. Klooster se uitspraak is dat die kerk 'n goeie teologie vir sy welwese benodig - en vandag selfs vir sy wese. Maar dan moet teologie slegs diens lewer. Teologie is nie die koningin van die wetenskappe nie. Teologie mag nie oor die kerk reageer nie. Teoloë mag spesialiste wees maar hulle is nie gesaghebbendes nie. Omdat ongenoegsame kennis van die kerk die grootste bedreiging vir die kerk is, moet teoloë nuwe entoesiasme vir die kerk aankweek. En dan volg hierdie besondere woorde: „The church has not really outgrown the confessions; the church needs to grow up to the heights of the Reformed confessions"

Meer as ooit tevore het die kerk die goeie dienste van teolö̈ nodig - nie ketterse teoloë nie. Van die kant van die kerk moe daar egter meer begrip vir die probleme van die teoloog kom. 
Klooster se konklusie is: In Taiwan was hy geskok toe hy 'n afgodefabriek sien. Maar toe hy nagedink het, het hy besef: in die Weste is die afgodefabrieke in die teologiese skole. 1 Johannes 5 : 21 moet as ernstige waarskuwing vir ons dien.

\section{Kommentaar van Arent 1. de Graaf op Klooster se referaat:}

Sommige mense is doodbang vir 'n konfessie en sing 'n populêre liedjie: "Don't fence me in". Dit is nie nodig om bang te wees nie, as 'n mens gedagtig is aan die Griekse woorde: homologia (dieselfde sê) en paratheke (wat aan jou oorhandig is). Hierdie twee woorde dui die funksie van die konfessie in die kerk aan - mits ons soos 'n Samuel vir die Here vra: Spreek, want u kneg hoor. Binne die Woord moet daar vryheid aan die teoloë gegee word, maar nooit mag die kerk aan teoloë die reg gee om maatstawwe buite die Woord te gaan soek nie. Die goeie orde bind die teoloë en onsself aan die konfessie. Laat die teologie vry wees van die filosofie van die wêreld - as daar iets vreemds in jou oog is kan jy nie reg sien nie.

Derde referaat: Central issues in current theology deur W. $H$. Velema:

Hierdie referaat het reeds In die Skriflig van Desember 1976 verskyn (Jaargang 11, Nommer 40) onder die opskrif: Moderne theologie en het Neo-Marxisme, verenigd in de Wereldraad van Kerken. Daarom gee ons nie hier ' $n$ opsomming van hierdie referaat nie.

Prof. Tjaart van der Walt het in sy kommentaar met groot waardering van die inhoud van die voordrag gepraat. Hy het die volgende onder aandag gebring:

1. Ons moet waak teen 'n toename van polarisasie onder teoloë as gevolg van oorreaksie.

2. Die teoloog se beskouing oor die eerste hoofstukke van die Bybel beïnvloed sy interpretasie van die Evangelie.

(Gelewer voor G.T.V. Pretoria, Maart 1977) 